\title{
Higher Education Course Content: Paper-Based, Online or Hybrid Course Delivery?
}

\author{
Glen Van der Vyver and Michael S Lane \\ University of Southern Queensland, Toowoomba, Australia
}

\author{
vandervy@usq.edu.au; lanem@usq.edu.au
}

\begin{abstract}
The emergence of the Internet has made many institutions involved in the delivery of distance education programs re-evaluate the course delivery framework. A variety of models and techniques co-exist in an often uneasy alliance at many such institutions. These range from the traditional distance learning model, which remains paper-based, to the purely online model. Recently, hybrid models have emerged which apparently attempt to forge elements taken from several models into a unified whole. Many of these hybrid models seek to eliminate paper-based materials from the tuition process. While many arguments are put forward about the efficacy of purely electronic delivery mechanisms, cost containment is often the driving motivation. This study explores student perceptions of the various delivery mechanisms for distance learning materials. In particular, it seeks to determine what value students place on paper-based delivery mechanisms. The study surveys a group of undergraduate students and a group of graduate students enrolled in the Faculty of Business at a large regional Australian university.
\end{abstract}

Keywords: Hybrid model, Distance education, Distance Learning, Online education

\section{Introduction}

The rapid growth and apparent ubiquity of the Internet has the potential to drive a revolution in education, particularly in regards to the delivery of courses (Bleed, 2001; Brown, 2002; Carnevale, 1999). Indeed, for those in the global village who have access to the technological infrastructure required to participate in the new educational paradigm, the revolution is a fact rather than a potentiality. The tertiary sector has already witnessed significant upheavals as it has responded to the new paradigm over the best part of a decade, while recent initiatives have coopted the secondary sector into the change process. Even the primary sector will in due course be fully exposed to the winds of change.

Before the advent of the Internet, most students studied in the traditional on-campus mode with a significant minority studying in various distance learning formats (Carnevale, 1999; Cragg, Andrusyszyn, \& Humbert, 1999; Dibiase, 2000; Nichols \& Gardner, 2002). Most distance learning courses were based on printed materials. The Internet and a variety of technologies that have evolved roughly at the same time have opened up the possibility of many new delivery mecha-

Material published as part of this journal, either on-line or in print, is copyrighted by Informing Science. Permission to make digital or paper copy of part or all of these works for personal or classroom use is granted without fee provided that the copies are not made or distributed for profit or commercial advantage AND that copies 1) bear this notice in full and 2) give the full citation on the first page. It is permissible to abstract these works so long as credit is given. To copy in all other cases or to republish or to post on a server or to redistribute to lists requires specific permission from the publisher at Publisher@InformingScience.org nisms, including the purely online mode. We are now almost spoilt for choice as regards course delivery mechanisms and many argue that the tertiary course of the future will incorporate a variety of delivery mechanisms - the hybrid model (Brown, 
2001; Cavanaugh, 2000; Largo, 2000; Martyn, 2003).

The paper briefly reviews hybrid models in general and a model proposed for a regional Australian university. We examine the potential for cost savings of a course delivery system based upon CD technology, as well as other benefits associated with such an approach. We then present the results of a survey of students in two courses at the same university. The study examines the perceptions of students as regards the desirability and suitability of various course delivery mechanisms which form part of the proposed hybrid model, with particular reference to students perceptions regarding 'value' and 'cost'.

\section{Impact of the Internet on Higher Education}

The advent of organisations like Fathom, a virtual organisation operating for profit in the tertiary sector, caused some to predict the end of the 'brick and mortar' institution, which would not be able to compete with the virtual university. Simply put, the 'traditional' university had too many overheads and was unable to adapt as rapidly to change as the virtual university, which is exceptionally adaptable and adhocratic (Pethokoukis, 2002). Fathom and a number of other aggressive, well-funded virtual university initiatives have floundered after brief life spans. Indeed, Columbia University recently shut down the Fathom virtual university initiative. Thirty million dollars had been invested in Fathom but the virtual University initiative had failed to generate any significant revenue (Beam, 2004). While a number of online initiatives, such as those at Pennsylvania State University and the University of Maryland, have potential nobody is making money at this juncture (Wilson, 2002). Clearly the Internet has had an impact, but even the CEO's of the most aggressive of online universities are now adopting a more measured tone.

The belief in the assured future of the virtual university delivering web-based courses has been replaced by a more holistic approach, where video and the WWW are 'used to enhance a classroom, not replace it.' (Pethokoukis, 2002, p. 1). Wilson (2002) argues that one of the problems has been too much focus on technology and too little focus on what students need and want. He argues that another mistaken viewpoint is that content is king, whereas content is actually the least valuable part of the education value chain.

Pethokoukis (2002) examines the University of Phoenix as a success story - 34000 students and 10000 online degrees completed. Their model, he argues, is not based on complex commercial contracts. Rather, they chose a student-centred approach based upon relationship building. Wilson (2002) concurs, arguing those institutions that have has some measured successes in the online environment have done so without becoming involved in complex relationships with corporations. This is because the value chains of commercial organisations and institutions of higher education are fundamentally different. Indeed, there is usually little middle ground in this uneasy mix of cultural opposites - "universities strive for access, quality, research excellence, service and teaching for teaching's sake, a corporation is driven by financial considerations first" (Wilson, 2002, p. 7).

\section{The Emergence of the Hybrid Model}

The hybrid model for the delivery of educational courses involves the use of a variety of delivery mechanisms and forms, ranging from the traditional lecture to online discussion groups and streaming video (Bleed, 2001; Garnham \& Kaleta, 2002; Martyn, 2003; Spilka, 2002). Koohang and Durante (2003) argue that technology is becoming pervasive in all forms of educational delivery, all part of the quest for education anywhere, anytime, and anyplace. They point out that an increasing number of universities are now experimenting with the hybrid model but often the emphasis is on the use of the hybrid model within a traditional, campus-based modality. In this setting, education has a real-time, face-to-face focus, but this focus is supplemented by a variety of 
Web-based elements, This reduces the amount of time students spend in class and allows for dialogue to continue on a continuous basis (Echimof, 2000; Koohang \& Durante, 2003; Young, 2002).

Wilson (2002) identifies the potential of the hybrid model to deliver more than course materials or learning, but a total educational experience. Students, he argues, want to experience the university at which they are enrolled. They want virtual classrooms, the opportunity to interact with faculty, other students, a virtual library, and more. The reputation and facilities of the university are also important.

It is surprising that more research has not been done on the potential of the hybrid model to support on-campus learning than off-campus or distance learning. It could be argued that the greatest potential impact of the hybrid model is in the distance learning arena. This study examines the situation at a regional university that offers instruction in a variety of formats, ranging from the traditional on-campus mode to a purely online mode.

Fister (1998) argues that the enduring problems with Internet bandwidth makes the CD-ROM an ideal interim solution for providing students with a variety of media in a single package. This often vivid multimedia approach enriches the learning experience and can be integrated with additional material available on the Web. This type of delivery mechanism would of course be highly suited to the delivery of materials to external students (Cavanaugh, 2000; Simpson, Payne, Munro, \& Hughes, 1999). Clearly, the technology has many advantages, such as cost savings, portability and the ability of the $\mathrm{CD}$ to act as a delivery mechanism for a large variety of file formats. Although Fister (1998) envisaged CD-ROM technology as an interim solution, bandwidth problems still remain as do problems of limited access (or no access) to the Internet.

One of the most important advantages of CD-ROM technology is that it is capable of delivering such a wide variety types of educational materials (Fister, 1998). Thus, on a single CD, we could for example have:

- Introductory Book

- Study Guide/s

- $\quad$ Video files

- Graphics files

- Books of Selected Readings

- PowerPoint slides

- $\quad$ Audio files

- Multimedia

- User manuals

Although the actual delivery mechanisms may need to vary according to the location of the student, the CD-ROM would become the primary mechanism for the delivery of educational materials. Some institutions might choose to make the $\mathrm{CD}$ a self-standing learning package while others might use the $\mathrm{CD}$ and a combination of other delivery methods. Examples of these configurations might include:

- On-Campus: $\mathrm{CD}$, practicals, lectures and tutorials.

- Off-Campus within commuting distance: $\mathrm{CD}$ and vacation schools. 
- Off-Campus and remote: $\mathrm{CD}$, e-mail, discussion groups, and telephone / video conferencing.

Thus, the CD becomes the core delivery mechanism and is supported a variety of other mechanism, some of which may only be used with particular groups of students (see Figure 1).

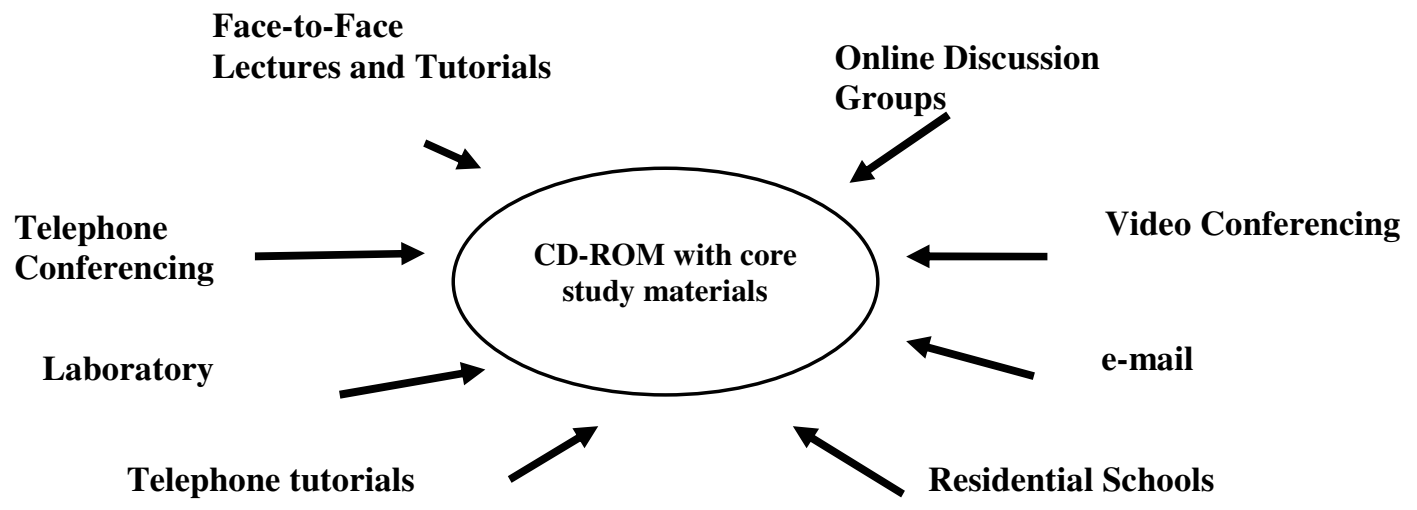

Figure 1: Educational delivery with CD-ROM technology at the core (Source: adopted from Fister (1998))

It is clear that a hybrid model based on the use of CD technology promises significant cost savings, particularly where it displaces a system which relies on the distribution of printed materials. CD's can be produced at a small fraction of the cost of print materials and the savings on distribution costs are perhaps even more dramatic. CD's also require less investment in expensive capital equipment and offer shorter production lead times and low replacements costs.

\section{Research Questions}

This study was undertaken within a specific context of a regional university in Australia which has a strong market position in 'traditional' distance education within the higher education sector. More recently the university has ventured into online education. This regional university now offers three main modes of delivery of its courses: face-to-face, distance education and online. The overwhelming majority of students who were surveyed are studying using the 'traditional' distance learning program. Thus, while a variety of value added learning elements such as discussion groups and e-mail are available, the delivery of courses is largely based on printed materials. We argue that the respondents to our survey will have a comparative view when it comes to assessing and evaluating the proposed hybrid model. They are likely to compare the value they derive from the course materials under the hybrid model to the value they currently derive. It might be that students who have never undertaken tertiary study have a significantly different approach.

This study was designed to address the following research objectives which also translate into the research questions for this first phase of this study:

- How important do students perceive the different delivery media for study materials to their study success?

- Which types of media for study materials are students frequently using?

- What are student media preferences for study materials when they presented with three delivery choices (Printed; CD; Web)? 
- When students are presented with CD media delivery of study materials as the primary delivery mode, would students also want a printed copy of the study materials?

- If CD media delivery of study materials is the primary delivery mode for study materials, would students be willing to pay extra to course fees for a printed copy of the study materials?

- If students are willing to pay for a printed copy of the study materials, how much would they be willing to pay?

\section{Research Method}

The research methodology employed in this study was primarily quantitative in nature. However, there were aspects of the study which were qualitative as we also collected some qualitative data in response to the open ended questions we posed to students surveyed in this study. The triangulation of quantitative and qualitative data improves the validity of research findings (Gable, 1994). The qualitative data collected in our survey allowed us to triangulate our findings from the quantitative data collected. An email survey was conducted to collect data to address the research objectives/questions outlined above. While we acknowledge that there are some shortcomings in an email survey, it did allow us to administer the survey in a quick and efficient manner. Using a five-point Likert scale, we surveyed a cohort of students in a postgraduate course and a cohort of students in an undergraduate course about their perceptions of different types of media delivery of course study materials that are currently being offered or could be offered in the future. The postgraduate course was management focused and was concerned with the strategic use of the Internet in organisations. The undergraduate course was technology focused and was concerned with developing database systems. The postgraduate course was delivered in face-to-face, traditional distance and online modes. The undergraduate course was delivered in face-to-face, traditional distance and online modes. Both courses allowed students to access some or all of the study materials online, while communication with the lecturers and tutors was by face-to-face, phone, email or discussion boards. Therefore, both courses were providing components of a hybrid model of education to students.

The survey was sent out by email with the students providing their responses to the questionnaire in a reply email or in a file attachment in the reply email. The response to the email survey was about 19 percent with 116 useable responses from an overall sample size of 600. This is an acceptable response rate for Internet based surveys given that a response rate of 5-10 percent is common for online surveys (Lang, 2002; Newstead, Huff, Munro, \& Schwarz, 2003). Furthermore, the respondents were required to type in their responses to the survey questions in their reply email and it is also possible that a significant number of the e-mails did not reach the recipients.

Non-response bias was tested by randomly selecting and contacting twenty non-respondents from each course (postgraduate, undergraduate) and asking them to answer the demographic questions from the survey. Chi square tests showed that there were no significant differences between respondents and non-respondents in the study. The quantitative survey data was analysed by comparing the means of the questions related to course materials. The differences between the postgraduate and undergraduate courses were compared using Chi square tests. The qualitative data collected in the survey was analysed using the qualitative data management software package NVivo. This software package allowed the researcher to manage the coding of themes in the qualitative responses of the survey respondents and be able to retrieve common themes across all of the respondents in relation to specific research questions. Direct quotations from respondents were included the data analysis section in relation to different research questions to emphasise the key findings that emerged from the data. The legend for the direct quotations is as follows: $\mathrm{P}=$ 
paragraph and number. For instance $\mathrm{P} 10=$ paragraph 10 from the transcript of the qualitative comments by the respondents.

\section{Data Analysis and Findings}

In this section, the findings in relation to demographics of survey respondents and survey respondents' answers to the survey questionnaire are presented and discussed.

\section{Demographics of survey respondents}

First, we collected the demographics about the survey respondents such as their age, gender and Internet experience. The demographics of respondent students are discussed first to provide an overview of the postgraduate and undergraduate students surveyed in this study. Table 1 presents a summary of the distribution of student age in the survey respondents across postgraduate and undergraduate degrees.

Table 1 Distribution of student age across postgraduate and undergraduate degrees

\begin{tabular}{|l|l|l|l|l|}
\hline Level of study & Age range & Frequency & $\begin{array}{l}\text { Valid Per- } \\
\text { cent }\end{array}$ & $\begin{array}{l}\text { Cumulative } \\
\text { Percent }\end{array}$ \\
\hline Postgraduate & $\begin{array}{l}\text { Less than or equal 20 } \\
\text { yrs }\end{array}$ & 1 & 1.4 & 1.4 \\
\hline & $\begin{array}{l}\text { between 21 years and } \\
30 \text { yrs }\end{array}$ & 25 & 34.7 & 36.1 \\
\hline & $\begin{array}{l}\text { Between 31 years } \\
\text { and 40 yrs }\end{array}$ & 27 & 37.5 & 73.6 \\
\hline & Over 40 yrs & 19 & 26.4 & 100.0 \\
\hline & Total & 72 & 100.0 & \\
\hline Undergraduate & $\begin{array}{l}\text { Less than or equal 20 } \\
\text { yrs }\end{array}$ & 8 & 18.2 & 18.2 \\
\hline & $\begin{array}{l}\text { between 21 years and } \\
30 \text { yrs }\end{array}$ & 26 & 59.1 & 77.3 \\
\hline & $\begin{array}{l}\text { Between 31 years } \\
\text { and 40 yrs }\end{array}$ & 6 & 13.6 & 90.9 \\
\hline & Over 40 yrs & 4 & 9.1 & 100.0 \\
\hline & Total & 44 & 100.0 & \\
\hline
\end{tabular}

The majority of respondents were postgraduates and there was a clear difference between the age profiles of the undergraduate and postgraduate groups. The results of the Chi square tests in Table 2 show that the postgraduate and undergraduate students are different cohorts in terms of their age distribution

Table 2 Chi-Square Tests of student age distribution for postgraduate and undergraduate

\begin{tabular}{|l|r|r|r|}
\hline & Value & df & $\begin{array}{c}\text { Asymp. Sig. } \\
\text { (2-sided) }\end{array}$ \\
\hline $\begin{array}{l}\text { Pearson Chi- } \\
\text { Square }\end{array}$ & $23.204(\mathrm{a})$ & 3 & .000 \\
\hline Likelihood Ratio & 24.477 & 3 & .000 \\
\hline N of Valid Cases & 116 & & \\
\hline
\end{tabular}


Table 3 presents a summary of gender distribution across the postgraduate and undergraduate respondents in the email survey. Male and females were evenly represented in the postgraduate respondents while females are underrepresented in the undergraduate respondents in the email survey.

Table 4 Distribution of Gender across postgraduate and undergraduate degrees

\begin{tabular}{|l|l|l|l|l|}
\hline & Gender & Frequency & Valid Percent & Cumulative Percent \\
\hline Postgraduate & Male & 36 & 50.0 & 50.0 \\
\hline & Female & 36 & 50.0 & 100.0 \\
\hline & Total & 72 & 100.0 & \\
\hline Undergraduate & Male & 29 & 65.9 & 65.9 \\
\hline & Female & 15 & 34.1 & 100.0 \\
\hline & Total & 44 & 100.0 & \\
\hline
\end{tabular}

This under representation of females in the undergraduate responses can perhaps be explained by the technological nature of the undergraduate course. In the postgraduate course, which has a managerial strategic focus to IT, there was much less emphasis on in depth technical knowledge. The distribution of gender across the postgraduate and undergraduate courses was not signifi-

Table 3 Chi-Square Tests of Distribution of Gender across postgraduate and undergraduate degrees

\begin{tabular}{|l|r|r|r|r|r|}
\hline & Value & \multicolumn{1}{|c|}{ df } & $\begin{array}{c}\text { Asymp. Sig. } \\
\text { (2-sided) }\end{array}$ & $\begin{array}{c}\text { Exact Sig. } \\
\text { (2-sided) }\end{array}$ & $\begin{array}{c}\text { Exact Sig. } \\
\text { (1-sided) }\end{array}$ \\
\hline $\begin{array}{l}\text { Pearson Chi- } \\
\text { Square }\end{array}$ & $2.806(\mathrm{~b})$ & 1 & .094 & & \\
\hline $\begin{array}{l}\text { Continuity Cor- } \\
\text { rection(a) }\end{array}$ & 2.197 & 1 & .138 & & \\
\hline Likelihood Ratio & 2.839 & 1 & .092 & & .069 \\
\hline $\begin{array}{l}\text { Fisher's Exact } \\
\text { Test }\end{array}$ & & & & .123 & \\
\hline N of Valid Cases & 116 & & & & \\
\hline
\end{tabular}

b 0 cells $(.0 \%)$ have expected count less than 5 . The minimum expected count is 19.34 .

cantly different as shown in the Chi square tests in Table 4.

Table 5 presents a summary of Internet experience across the postgraduate and undergraduate respondents in the email survey. 
Table 6 Distribution of Internet Experience across postgraduate and undergraduate degrees

\begin{tabular}{|l|l|l|l|l|}
\hline Level of study & $\begin{array}{l}\text { Years of Internet } \\
\text { Experience }\end{array}$ & Frequency & $\begin{array}{l}\text { Valid Per- } \\
\text { cent }\end{array}$ & $\begin{array}{l}\text { Cumulative } \\
\text { Percent }\end{array}$ \\
\hline Postgraduate & 1-2 years & 6 & 8.3 & 8.3 \\
\hline & 3-5 years & 9 & 12.5 & 20.8 \\
\hline & Over 5years & 57 & 79.2 & 100.0 \\
\hline & Total & 72 & 100.0 & \\
\hline Undergraduate & 1-2 years & 1 & 2.3 & 2.3 \\
\hline & 3-5 years & 17 & 38.6 & 40.9 \\
\hline & Over 5years & 26 & 59.1 & 100.0 \\
\hline & Total & 44 & 100.0 &
\end{tabular}

Not surprising, the level of Internet experience was slightly less in the postgraduate students with 91.7 percent of these respondents having 3 or more years Internet experience. In contrast, 97.7 percent of the undergraduate students have 3 or more years Internet experience. However, the level of Internet experience was generally high across all students surveyed. The distribution of the level of Internet experience across the postgraduate and undergraduate courses was significantly different as showed in the Chi square tests

Table 5 Chi-Square Tests Distribution of Internet Experience across postgraduate and undergraduate degrees

\begin{tabular}{|l|r|r|r|}
\hline & Value & \multicolumn{1}{|c|}{ df } & $\begin{array}{c}\text { Asymp. Sig. } \\
\text { (2-sided) }\end{array}$ \\
\hline $\begin{array}{l}\text { Pearson Chi- } \\
\text { Square }\end{array}$ & $11.524(\mathrm{a})$ & 2 & .003 \\
\hline Likelihood Ratio & 11.502 & 2 & .003 \\
\hline N of Valid Cases & 116 & & \\
\hline \multicolumn{3}{|c|}{ a 2 cells (33.3\%) have expected count less than 5. } \\
The minimum expected count is 2.66.
\end{tabular}
in Table 6.

\section{Perceived Value, Frequency of Use and Cost of Different Modes of Delivery of Study Materials}

Sixteen questions were used to measure the students' perceptions of the study materials and the various modes of media delivery based perceived value to study, frequency of use and cost. A five point Likert scale was used. Table 7 presents means of the mean average responses to these questions for the postgraduate students, sorted from highest to lowest (where 1 represents the lowest possible score and 5 the highest). 
Table 7 Postgraduate Perceptions of study materials offered in various modes

\begin{tabular}{|c|c|c|c|c|c|c|c|c|}
\hline $\begin{array}{l}\text { Student perceptions of } \\
\text { study materials }\end{array}$ & $\begin{array}{l}\text { No of } \\
\text { re- } \\
\text { sponses }\end{array}$ & SD & D & $\mathbf{N}$ & $\mathbf{A}$ & $\mathbf{S A}$ & Mean & $\begin{array}{l}\text { Standard } \\
\text { Deviation }\end{array}$ \\
\hline $\begin{array}{l}\text { Student frequently uses } \\
\text { printed study book }\end{array}$ & 69 & 7 & 2 & 7 & 26 & 27 & 3.93 & 1.240 \\
\hline $\begin{array}{l}\text { Student considers printed } \\
\text { USQ study materials to be } \\
\text { of great value }\end{array}$ & 71 & 2 & 9 & 6 & 31 & 23 & 3.90 & 1.084 \\
\hline $\begin{array}{l}\text { Student considers printed } \\
\text { study book important for } \\
\text { their success }\end{array}$ & 69 & 3 & 7 & 11 & 27 & 22 & 3.88 & 1.078 \\
\hline $\begin{array}{l}\text { Student considers printed } \\
\text { introductory book impor- } \\
\text { tant for their success }\end{array}$ & 70 & 5 & 12 & 9 & 22 & 21 & 3.83 & 1.116 \\
\hline $\begin{array}{l}\text { Online discussion groups } \\
\text { are valuable }\end{array}$ & 70 & 4 & 7 & 12 & 27 & 20 & 3.74 & 1.151 \\
\hline $\begin{array}{l}\text { Student frequently visits the } \\
\text { Online discussion groups }\end{array}$ & 72 & 7 & 10 & 10 & 21 & 24 & 3.62 & 1.337 \\
\hline $\begin{array}{l}\text { Student frequently uses the } \\
\text { printed introductory book }\end{array}$ & 69 & 5 & 12 & 9 & 22 & 21 & 3.61 & 1.286 \\
\hline $\begin{array}{l}\text { Students considers printed } \\
\text { selected readings important } \\
\text { for their success }\end{array}$ & $70 * * * *$ & 6 & 11 & 13 & 22 & 18 & 3.50 & 1.271 \\
\hline $\begin{array}{l}\text { Student frequently uses } \\
\text { printed selected readings }\end{array}$ & 70 & 6 & 12 & 16 & 19 & 17 & 3.41 & 1.268 \\
\hline $\begin{array}{l}\text { Student prefers the study } \\
\text { materials on Web Site }\end{array}$ & 72 & 10 & 12 & 14 & 21 & 15 & 3.26 & 1.343 \\
\hline $\begin{array}{l}\text { Student prefers study mate- } \\
\text { rials on CD }\end{array}$ & 72 & 12 & 17 & 14 & 18 & 11 & 2.99 & 1.337 \\
\hline $\mathrm{CD}$ is costlier for student & $71 * * * *$ & 12 & 20 & 20 & 11 & 8 & 2.76 & 1.236 \\
\hline $\begin{array}{l}\text { It is beneficial to have } \\
\text { study materials on Web }\end{array}$ & 72 & 21 & 18 & 11 & 12 & 10 & 2.61 & 1.420 \\
\hline $\begin{array}{l}\text { It is beneficial to have the } \\
\text { study materials on CD }\end{array}$ & 71 & 20 & 17 & 16 & 8 & 10 & 2.59 & 1.379 \\
\hline $\begin{array}{l}\text { CD is Costlier for Univer- } \\
\text { sity }\end{array}$ & 72 & 19 & 20 & 22 & 4 & 7 & 2.44 & 1.221 \\
\hline $\begin{array}{l}\text { It is better to study with } \\
\text { study materials on CD }\end{array}$ & 70 & 22 & 18 & 17 & 7 & 6 & 2.39 & 1.266 \\
\hline
\end{tabular}

It was evident from the responses to questions (bolded rows in Table 7) that the postgraduate students consider the study materials to be very important to their study and it would appear to be a significant preference for the printed study materials. The following comment by a postgraduate student in the survey emphasizes the importance placed by postgraduate students on the printed study materials.

"I take my printed material everywhere; this option is not available on CD and would require me to re-print all documentation. I make notes, highlight and take any opportunity I can to catch up on my reading. This is not possible with a $\mathrm{CD}$; it would require me to plan more carefully my day 
to day study instead of being able to throw everything into my work bag. I also make notes and highlight points of importance or reference which I use when studying and doing assignments which I flick through in the books - this is also not possible with CD.” (P:31:33).

However many students also felt that a CD copy of the study materials and making the study materials available on the Web was also beneficial as well as noted in the following comment by a postgraduate student. "If our work requires us to working overseas at times, printed materials

Table 8 Undergraduate Perception of study materials offered in various modes

\begin{tabular}{|c|c|c|c|c|c|c|c|c|}
\hline Student Perceptions Questions & $\begin{array}{l}\text { No of } \\
\text { valid re- } \\
\text { sponses }\end{array}$ & SD & $\mathbf{D}$ & $\mathbf{N}$ & $\mathbf{A}$ & $\mathbf{S A}$ & Mean & $\begin{array}{l}\text { Stan- } \\
\text { dard } \\
\text { Devia- } \\
\text { tion }\end{array}$ \\
\hline $\begin{array}{l}\text { Student frequently visits the } \\
\text { Online discussion groups }\end{array}$ & 42 & 2 & 3 & 5 & 13 & 19 & 4.05 & 1.147 \\
\hline $\begin{array}{l}\text { Online discussion groups are } \\
\text { valuable }\end{array}$ & 42 & & 5 & 6 & 18 & 13 & 3.93 & .973 \\
\hline $\begin{array}{l}\text { Student considers printed intro- } \\
\text { ductory book important for their } \\
\text { success }\end{array}$ & 43 & 2 & 4 & 6 & 15 & 16 & 3.91 & 1.151 \\
\hline $\begin{array}{l}\text { Student frequently uses printed } \\
\text { study book }\end{array}$ & 43 & 2 & 3 & 7 & 17 & 14 & 3.88 & 1.096 \\
\hline $\begin{array}{l}\text { Student considers printed study } \\
\text { book important for their success }\end{array}$ & 43 & 2 & 3 & 11 & 13 & 14 & 3.79 & 1.125 \\
\hline $\begin{array}{l}\text { Student frequently uses printed } \\
\text { introductory book }\end{array}$ & 43 & 4 & 5 & 6 & 16 & 12 & 3.63 & 1.273 \\
\hline $\begin{array}{l}\text { Student considers printed USQ } \\
\text { study materials to be of great } \\
\text { value }\end{array}$ & 43 & 3 & 9 & 9 & 13 & 9 & 3.37 & 1.235 \\
\hline $\begin{array}{l}\text { Student prefers the study materi- } \\
\text { als on Web Site }\end{array}$ & 42 & 8 & 9 & 8 & 6 & 11 & 3.07 & 1.488 \\
\hline CD is costlier for student & $41 * * * *$ & 11 & 3 & 12 & 4 & 11 & 3.02 & 1.541 \\
\hline $\begin{array}{l}\text { Students considers printed se- } \\
\text { lected readings important for } \\
\text { their success }\end{array}$ & $43 * * * *$ & 6 & 5 & 18 & 10 & 4 & 3.02 & 1.144 \\
\hline $\begin{array}{l}\text { Student frequently uses printed } \\
\text { selected readings }\end{array}$ & 42 & 7 & 9 & 12 & 9 & 5 & 2.90 & 1.265 \\
\hline $\begin{array}{l}\text { Student prefers study materials } \\
\text { on } C D\end{array}$ & 42 & 11 & 10 & 7 & 6 & 8 & 2.76 & 1.478 \\
\hline CD is Costlier for University & 41 & 11 & 5 & 16 & 4 & 5 & 2.68 & 1.312 \\
\hline $\begin{array}{l}\text { It is beneficial to have study ma- } \\
\text { terials on Web }\end{array}$ & 42 & 15 & 9 & 10 & 4 & 4 & 2.36 & 1.322 \\
\hline $\begin{array}{l}\text { It is beneficial to have the study } \\
\text { materials on CD }\end{array}$ & 42 & 19 & 5 & 9 & 6 & 3 & 2.26 & 1.363 \\
\hline $\begin{array}{l}\text { It is better with study materials } \\
\text { on } C D\end{array}$ & 42 & 15 & 12 & 8 & 4 & 3 & 2.24 & 1.246 \\
\hline
\end{tabular}


would be cumbersome. CD or the Web is definitely useful to us" (P:195).

Importantly, the postgraduate student respondents felt that CD delivery was less costly for the university but it was also less beneficial to study with the study materials only available on the CD. Students felt that they incurred additional cost with the CD delivery of the study materials because the cost of printing a hard copy of the study materials has to be borne by the student.

"It seems that this whole survey is about trying to save money. May be should realise that it's because of the current great levels of service that it has earned awards in the Good Universities Guide. It's sad to note that ... wants to follow the path of other unsavoury institutions in this country (like the banks and the federal government) and either cut costs or pass on the costs to its customers" (P:378).

Table 8 presents the means of the undergraduate responses to sixteen questions used to measure student perceptions of the study materials and the various modes of media delivery based perceived value to study, ease of use and cost. A discussion of the interesting findings relating to these responses follows Table 8.

Interestingly, the undergraduate students considered the online discussion groups to be the most beneficial to their study in contrast to the postgraduate students who did not consider the online discussion groups as important.

"Please take advantage of the discussion board which is best way to communicate between course leader and students." (P:653).

However, the undergraduate students also rated the printed study materials to be very important and they felt that printed study materials contributed greatly to their study success.

"I think the cost of the study materials is fair at the moment and of course $\mathrm{i}$ wouldn't want that to change, but having the study materials online instead of in printed format would result in me studying less, and probably end up jeopardizing my results, so i would be prepared to pay a little bit extra to ensure $i$ have the study materials in printed format. There's no point in risking failing a 500 dollar unit, plus the effects to your GPA just for the sake of saving 20 dollars from having your books in printed format" (P:484:485).

Another major difference between the two cohorts of students was that the undergraduate students did not rate the printed selected readings as being as important to their study success as the postgraduate students. This difference can be possibly explained again by the technical nature of the undergraduate course which is a very applied and hands on course versus the strategic managerial nature of the postgraduate course. The undergraduate students felt that CD media delivery of the course materials would be costlier to them, however the undergraduate still rated the CD media delivery of course materials positively overall with a mean of 2.76 although the size of standard deviation indicate a wider range of views on this issue. Overall, the undergraduate students rated the CD media and Web media delivery of study materials negatively with the lowest means scores of 2.36, 2.26 and 2.24 respectively.

"My preference, strictly for myself, would be for materials to be on CD or on a Web site, however that may not suit all students. For the fees that students (especially external students) are paying, they should have a choice of delivery methods that suit them, not be forced into the option that favours the University" (P:407).

Interestingly, this finding was in contrast with the postgraduate students who rated the benefits of $\mathrm{CD}$ media and Web media delivery of study materials lower but the corresponding mean scores of 2.61 and 2.59 for these questions were above the midpoint of 2.5.

"However if you are considering electronic format of our study material, CD format will be a better choice because it is more convenient to bring along wherever we go.", I think this is an extra 
advantage (the university) provide to its MBA student. As I said, CD is good, and it does not cost much!" (P8:10:12).

This may imply that the postgraduate students are more receptive to the hybrid delivery model for study materials. However it was evident from the qualitative date collected in the email survey that there are still some strong reservations about CD media and Web media delivery of study materials for both postgraduate and undergraduate students.

\section{Choice of Delivery Media for Study Materials}

In the email survey we also asked the students which type of delivery media they preferred for their study materials. Table 9 presents a summary of the results in relation to students' preference for one type of delivery media for their study materials. A discussion of the findings in relation to Table 6 follows.

Table 9 Choice of Delivery Media of Study Materials across Postgraduate and Undergraduate Degrees

\begin{tabular}{|l|l|l|l|l|l|}
\hline Level of Study & $\begin{array}{l}\text { Type of Study Mate- } \\
\text { rials }\end{array}$ & Frequency & Percentage & $\begin{array}{l}\text { Valid } \\
\text { Percent }\end{array}$ & $\begin{array}{l}\text { Cumulative } \\
\text { Percent }\end{array}$ \\
\hline Postgraduate & $\begin{array}{l}\text { Printed Study Materi- } \\
\text { als }\end{array}$ & 38 & 52.8 & 52.8 & 52.8 \\
\hline & $\begin{array}{l}\text { Web based Study Ma- } \\
\text { terials }\end{array}$ & 21 & 29.2 & 29.2 & 82.0 \\
\hline & CD Study Materials & 13 & 18.1 & 18.1 & 100.0 \\
\hline & Total & 72 & 100.0 & 100.0 & \\
\hline Undergraduate & $\begin{array}{l}\text { Printed Study Materi- } \\
\text { als }\end{array}$ & 33 & 75.0 & 80.5 & 80.5 \\
\hline & CD Study Materials & 5 & 11.4 & 12.2 & 92.7 \\
\hline & $\begin{array}{l}\text { Web based Study Ma- } \\
\text { terials }\end{array}$ & 3 & 6.8 & 7.3 & 100.0 \\
\hline & Total & 41 & 93.2 & 100.0 & \\
\hline & Missing System & 3 & 6.8 & & \\
\hline & & 44 & 100.0 & &
\end{tabular}

The results of student responses to their preference for one type of media delivery reinforced the findings in relation to the responses to sixteen questions presented in Tables 7 and 8 . Eighty percent (80.5) of undergraduate students overwhelmingly showed a preference for printed study materials in contrast to 52.8 percent of the respondent postgraduate students indicating a preference for printed study materials. This finding was confirmed by the Chi square tests in Table 10 which

Table 10 Chi-Square Tests Choice of Delivery Media of Study Materials across postgraduate and undergraduate degrees

\begin{tabular}{|l|r|r|r|}
\hline & Value & df & Asymp. Sig. (2-sided) \\
\hline $\begin{array}{l}\text { Pearson Chi- } \\
\text { Square }\end{array}$ & $9.628(\mathrm{a})$ & 2 & .008 \\
\hline Likelihood Ratio & 10.607 & 2 & .005 \\
\hline N of Valid Cases & 113 & & \\
\hline \multicolumn{4}{|c|}{ a 0 cells (.0\%) have expected count less than 5. } \\
The minimum expected count is 6.53.
\end{tabular}


show that there is a significant difference between the undergraduate students and the postgraduate students in their preference for media delivery of study materials.

The respondent postgraduate students indicated a higher preference for Web media delivery and CD media delivery with 29.2 percent and 18.1 percent respectively. This contrasted significantly with the responses of the undergraduate students with a preference for Web media delivery and CD media delivery of 7.3 percent and 12.1 percent respectively. Interestingly, the respondent postgraduate students rated Web media delivery of study materials higher than CD media delivery whereas the respondent undergraduate students rated CD media delivery of study materials much higher than Web media delivery.

\section{Preference for Printed Copy of Study Materials in CD-ROM De- livery of Study Material}

A number of universities are proposing a move towards CD-ROM based delivery of study materials and we wished to obtain an indication of how difficult it would be to persuade students to move from print based study materials to CD-Rom study materials. We therefore asked students whether, if CD media delivery of study materials was the primary delivery mode, they would also want a printed copy of the study materials and whether they would be willing to pay the printing costs for printed study materials. The results of the responses to these questions by the postgraduate and undergraduate students are presented in Tables 11 and 13 and a discussion of the findings drawn from these results follow.

It was evident from the results in Table 11, that both the respondent postgraduate and undergraduate students with 71 percent and 85 percent respectively, overwhelming indicated that they would want a printed copy of the study materials despite the study materials being offered primarily on CD media. The Chi Square tests in Table 12 which show that there is no significant difference between the undergraduate students and the postgraduate students in their preference for a printed copy of the study materials if CD-ROM is the primary media for delivery of study materials.

Table 11 Preference of postgraduate and undergraduate students for a printed copy of study materials if course materials are offered primarily on CD or the Web

\begin{tabular}{|l|l|l|l|l|l|}
\hline Level of study & $\begin{array}{l}\text { If Study materials are on } \\
\text { CD would you want a } \\
\text { printed copy of study } \\
\text { materials }\end{array}$ & Frequency & Percent & $\begin{array}{l}\text { Valid } \\
\text { Percent }\end{array}$ & $\begin{array}{l}\text { Cumulative } \\
\text { Percent }\end{array}$ \\
\hline Postgraduate & Yes Printed Materials & 51 & 70.8 & 76.1 & 76.1 \\
\hline & No Printed Materials & 16 & 22.2 & 23.9 & 100.0 \\
\hline & Total & 67 & 93.1 & 100.0 & \\
\hline & System Missing & 5 & 6.9 & & \\
\hline & Total & 72 & 100.0 & & \\
\hline Undergraduate & Yes Printed Materials & 35 & 79.5 & 85.4 & 85.4 \\
\hline & No Printed Materials & 6 & 13.6 & 14.6 & 100.0 \\
\hline & Total & 41 & 93.2 & 100.0 & \\
\hline & System Missing & 3 & 6.8 & & \\
\hline & Total & 44 & 100.0 & & \\
\hline
\end{tabular}


Table 12 Chi-Square Tests Preference of postgraduate and undergraduate students for a printed copy of study materials if course materials are offered primarily on CD or the Web

\begin{tabular}{|l|r|r|r|r|r|}
\hline & Value & \multicolumn{1}{|c|}{ Df } & $\begin{array}{c}\text { Asymp. Sig. } \\
\text { (2-sided) }\end{array}$ & $\begin{array}{c}\text { Exact Sig. } \\
\text { (2-sided) }\end{array}$ & $\begin{array}{c}\text { Exact Sig. } \\
\text { (1-sided) }\end{array}$ \\
\hline Pearson Chi-Square & $1.341(\mathrm{~b})$ & 1 & .247 & & \\
\hline $\begin{array}{l}\text { Continuity Correc- } \\
\text { tion(a) }\end{array}$ & .831 & 1 & .362 & & \\
\hline Likelihood Ratio & 1.390 & 1 & .238 & & \\
\hline Fisher's Exact Test & & & & & .327 \\
\hline N of Valid Cases & 108 & & & & \\
\hline
\end{tabular}

a Computed only for a $2 \times 2$ table

b 0 cells $(.0 \%)$ have expected count less than 5 . The minimum expected count is 8.35 .

This preference for printed study materials by the majority of postgraduate and undergraduate students is further supported by the following comments from survey respondents:

"I like the course pack because I get a checklist of materials I should be receiving and can chase up any outstanding materials before the semester starts. I also like to read the materials outside in the shade of our trees, CD and web formats would force me to work inside on the computer (P:17:C:290). I take my printed material everywhere; this option is not available on CD and would require me to re-print all documentation. I make notes, highlight and take any opportunity I can to catch up on my reading. This is not possible with a $\mathrm{CD}$, it would require me to plan more carefully my day to day study instead of being able to throw everything into my work bag" (P:31:C:210:154).

This finding was in contrast to 24 percent of the respondent postgraduate students and 14.6 percent of respondent undergraduate students who indicated that they did not want a printed copy of the study materials in addition to the CD media delivery of the study materials. These students have a strong preference for CD media or Web Media delivery of study materials which is supported in the following comments made by postgraduate and undergraduate students in relation to this question in the survey.

"However if you are considering electronic format of our study material, CD format will be a better choice because it is more convenient to bring along wherever we go. I think this is an extra advantage (the university) provide to its MBA student. As I said, CD is good, and it does not cost much!" (P:8:10:12).

"I love the freedom the web allows as I am able to roam/travel and can study while I am on the move rather than being tied down to attend lectures and only being able to travel o/s during semester breaks. Also I don't have to carry heavy readings as I can download on the run, use the online library resources and internet so I just carry one or 2 text books. A luxury !!!!","I wish the web course were available for starting times throughout the year so we could begin a course when we are read and not have to wait for the student timetable. That would be really GREAT flexible delivery" (P:122:123).

In asking the students whether they were willing to pay for a printed copy of the study materials in addition to the primary CD media delivery of study materials, we also asked the students how much they were willing to pay for a printed copy of the study materials in addition to the CD media delivery of the study materials. The results of this question are presented in Table 13. 
Table 14 Postgraduate and undergraduate students willingness to pay for a printed copy of study materials if course materials are offered primarily on CD or on the Web

\begin{tabular}{|l|l|l|l|l|l|}
\hline Level of study & $\begin{array}{l}\text { Would you be willing to } \\
\text { pay extra for a printed } \\
\text { copy of the study mate- } \\
\text { rials }\end{array}$ & Frequency & Percent & $\begin{array}{l}\text { Valid } \\
\text { Percent }\end{array}$ & $\begin{array}{l}\text { Cumulative } \\
\text { Percent }\end{array}$ \\
\hline Postgraduate & No Pay Extra & 31 & 43.1 & 60.8 & 60.8 \\
\hline & Yes, 0-20 Dollars & 17 & 23.6 & 33.3 & 94.1 \\
\hline & Yes, 20-40 Dollars & 2 & 2.8 & 3.9 & 98.0 \\
\hline & Yes, 40-60 Dollars & 1 & 1.4 & 2.0 & 100.0 \\
\hline & Total & 51 & 70.8 & 100.0 & \\
\hline & System missing & 21 & 29.2 & & \\
\hline & Total & 72 & 100.0 & & \\
\hline Undergraduate & No Pay Extra & 27 & 61.4 & 73.0 & 73.0 \\
\hline & Yes, 0-20 Dollars & 7 & 15.9 & 18.9 & 91.9 \\
\hline & Yes, 20-40 Dollars & 2 & 4.5 & 5.4 & 97.3 \\
\hline & Yes, 40-60 Dollars & 1 & 2.3 & 2.7 & 100.0 \\
\hline & Total & 37 & 84.1 & 100.0 & \\
\hline & System Missing & 7 & 15.9 & & \\
\hline & Total & 44 & 100.0 & & \\
\hline
\end{tabular}

The majority of postgraduate and undergraduate students were reluctant to pay more than twenty dollars for a printed copy of the study materials if CD-ROM was the primary delivery media for study materials. The Chi square tests in Table 14 show that there is no significant difference between the undergraduate students and the postgraduate students in their willingness to pay twenty dollars or less for a printed copy of the study materials if CD-ROM is the primary media for delivery of study materials.

Table 13 Chi-Square Tests of Postgraduate and undergraduate students willingness to pay for a printed copy of study materials if course materials are offered primarily on CD or on the Web

\begin{tabular}{|l|r|r|r|}
\hline & \multicolumn{1}{|c|}{ Value } & \multicolumn{1}{c|}{ df } & Asymp. Sig. (2-sided) \\
\hline $\begin{array}{l}\text { Pearson Chi- } \\
\text { Square }\end{array}$ & $2.273(\mathrm{a})$ & 3 & .518 \\
\hline Likelihood Ratio & 2.336 & 3 & .506 \\
\hline N of Valid Cases & 88 & & \\
\hline
\end{tabular}

a 4 cells $(50.0 \%)$ have expected count less than 5 . The minimum expected count is .84 .

Interestingly, 60.8 percent of the respondent postgraduate students and 70.8 of the respondent undergraduate students indicated that they were not willing to pay extra to their course fees for a printed copy of the study materials. The findings also show that 33.3 percent of the respondent postgraduate students and 18.9 percent of respondent undergraduate students were only willing to pay in the range of 0-20 dollars for the printed study materials. The reluctance of postgraduate and undergraduate students to pay only twenty dollars or less for a printed copy of the study ma- 
terials if CD-ROM was the primary delivery media for the study materials is supported in the following qualitative comments made by survey respondents:

"My printer cartridge costs are astronomical, and rely on quick connection speeds to download from the web sites. Should be given both.. Printing costs are huge - in this country a printer cartridge costs about $£ 30$ (55 AUS) and I go through about 3 per semester at least I currently don't get printed output but it probably costs me at least this much anyway to print them off from the Web" (P:8:9). "The course fees that increase every semester should be enough to cover the cost of both printed and multiple media delivery of study material" (P:172). "But I believe for the students they will lose out. The costs for printing the reading materials personally, would definitely be much, much higher than getting the books from the University" (P:318),

Not surprisingly, the respondent undergraduate students were even less reluctant to pay for a copy of the printed study materials. Seventy percent of the respondent undergraduate students were not willing to pay extra to their course fees for a printed copy of the study materials. In contrast only 18.9 percent of the respondent students willing to pay in the range of $0-20$ dollars for a printed copy of the study materials. The following qualitative comments by undergraduate survey respondents indicate a reluctant to pay for printed study materials.

"It's a poor university student, i already shell out approx $\$ 400$ a semester for books alone, factor in guild fees, stationary costs etc IF I HAD TO - YES 0-20 dollars","(no thank you, I have my intro law course on CD and it aggravates me to no end!" (P:611). "I think the cost of the study materials is fair at the moment and of course I wouldn't want that to change, but having the study materials online instead of in printed format would result in me studying less, and probably end up jeopardizing my results, so i would be prepared to pay a little bit extra to ensure I have the study materials in printed format. There's no point in risking failing a 500 dollar unit, plus the effects to your GPA just for the sake of saving 20 dollars from having your books in printed format" (P:484:485).

\section{Conclusions and Implications}

As we mentioned before, the group of students we surveyed are all accustomed to traditional, printed delivery mechanisms. While we believe that these results may be generalised to distance learning students who are accustomed to printed material, they must clearly be viewed with caution in other contexts. That being said, we are of the opinion that the strength of the preferences suggest that it would be worthwhile to survey people who have no experience of distance learning. We also stress that we are only interested in distance learning, off-campus students in this survey.

Students currently studying view the printed materials they receive from the university as valuable and consider the materials important for their success in study. Students make frequent usage of the materials and find them convenient. The materials were rated highly and there were a significant number of comments about the quality of the materials. In short, these materials clearly add value to the experience of being a student. We argue that the quality of the printed materials a student receives from a university can in itself be a source of differentiation, as word of mouth can be a very powerful medium for causing students to choose that university.

Although students are in favour of CDs being used as supplementary distribution mechanisms, there is strong resistance to the $\mathrm{CD}$ replacing printed materials entirely. The resistance is particularly strong amongst undergraduates who, perhaps paradoxically, also rate the value of the online discussion groups more highly than do postgraduates. The generally high ranking given to the online discussion groups indicated that students will embrace elements of a hybrid model which they perceive as adding positive value to the learning experience. 
We postulated that the issue of cost was of significant importance to the debate. As we have dis cussed, using CD's does involve significant cost reductions and students recognised this fact. A significant number perceived the potential introduction of CD's instead of printed materials as an attempt to shift costs onto the student. The issue of cost elicited more comment than any other, some of it highly emotive. Given the very large majority of students indicated that they would like to receive printed materials even if a CD was distributed as well, it is significant that there was strong resistance to paying additional money for these materials. While some student might be prepared to pay a nominal additional amount, we conclude that such initiatives would be resisted strongly and might even lead to an institution losing students.

For any tertiary institution contemplating moving to a CD-based course delivery system as discussed above, a well considered change management process is critical. In particular, we would recommend attention to the following points:

1. Extreme care should be taken to make sure that students do not perceive the change as a costcutting exercise on the part of the institution.

2. The worst case scenario is likely to emerge where students perceive a potential increase in costs combined with a decrease in 'value'.

3. If a CD-ROM based distribution mechanism is used, there is likely to be strong resistance from students if it delivers no more than the printed materials. Although further study will be required on this issue, we postulate that a set of CD's rich in content (in a variety of mediums) might be perceived as significantly enhancing the value of the educational experience. The creation of media rich $\mathrm{CD}$ content could however have implications as regards increased costs and decreased flexibility.

4. Broad consultation with all stakeholders is critical. It is important to have a significant understanding of the perceived value of the different components of the educational experience offered by the institution.

5. A fundamental question must be addressed: Are 'we' driven by technology or by the desire to best serve the needs of the student? This is not to say that tertiary institutions should not make use of the best and most current technologies available, but they should certainly address the capacity of those technologies to deliver an optimal educational experience.

\section{References}

Anderson, R. (2002). Security in open versus closed - The Dance of Boltzmann, Coase and Moore. Cambridge, UK: University of Cambridge.

Beam, C. (2004). Fathom.com shuts down as Columbia withdraws. Retrieved 22nd Febraury, 2004, from http://www.columbiaspectator.com/vnews/display.v/ART/2003/01/27/3e351727dea60

Bleed, R. (2001). A hybrid campus for a new millennium. EDUCAUSE Review, 36 (1).

Brown, D. G. (2001, August). Hybrid courses are best. Wake Forrest University in Syllabus: New Dimensions in Education Technology.

Brown, S. (2002). Re-engineering the university. Open Learning, 17, 231-243). Carfax Publishing.

Carnevale, D. (1999). Distance education can bolster the bottom line. Chronicle of Higher Education, 46 (9).

Cavanaugh, T. (2000). Web/CD Hybrid Model for the Distance Learning Environment. Retrieved 12th February, 2004, from http://www.unf.edu/ tcavanau/presentations/elearn/Web-cd-hybrid.pdf 
Cragg, C. E., Andrusyszyn, M. A., \& Humbert, J. (1999). Experience with technology and preferences for distance education delivery methods in a nurse practitioner program. Journal of Distance Education/Revue de l'enseignement à distance.

Dibiase, D. (2000). Is distance education a Faustian bargain? Journal of Geography in Higher Education, 24, 130-135). Carfax Publishing.

Echimof, G. (2000). Designing Web-based training: How to teach anyone anywhere anytime. Technical Communication, 47 (4).

Fister, S. (1998). The hybrid solution: Combining the Web with CD-ROM. Training, 35 (11).

Garnham, C., \& Kaleta, R. (2002). Introduction to hybrid courses. Teaching with Technology Today, 8 (6).

Koohang, A., \& Durante, A. (2003). Learner's perceptions towards the Web-based distance learning activities/assignments portion of an undergraduate hybrid instructional model. Journal Of Information Technology Education, 2.

Lang, M. (2002, April). The use of Web-based international surveys in information systems research. Paper presented at the The European Conference on Research Methodology for Business and Management Studies, Reading, United Kingdom.

Largo, M. E. (2000). The hybrid experience: How sweet it is! CONVERGE Magazine, 3 (9).

Martyn, M. (2003). The hybrid online model. Educause Quarterly (1).

Newstead, P., Huff, S., Munro, M., \& Schwarz, A. (2003). A tutorial on survey instruments. Retrieved 12th June, 2003, from http://www.isworld.org/surveyinstruments/tutor.htm

Nichols, M., \& Gardner, N. (2002). Evaluating flexible delivery across a tertiary institution. Open Learning, 17, 11-22). Carfax Publishing.

Pethokoukis, J. (2002). The ABC's of E-degrees. IT Magazine (Fall).

Simpson, M., Payne, F., Munro, R., \& Hughes, S. (1999). Using information and communications technology as a pedagogical tool: Who educates the educators? Journal of Education for Teaching, 25, 247262. Carfax Publishing.

Spilka, R. (2002). Approximately "real world" learning with the hybrid model. Teaching with Technology Today, 8 (6).

Wilson, J. (2002). Is there a future for online Ed?

Young, G. (2002, March 22). Hybrid teaching seeks to end the divide between traditional and online instruction. Chronicle of Higher Education, 33-34.

\section{Biographies}

Glen Van Der Vyver is a senior lecturer in Information Systems at the University of Southern Queensland. He worked at the "coalface," in Human Resources and IT (mostly), for around fifteen years before becoming an academic. He leads the database "stream" and teaches the core database courses. Glen has a varied academic background and research interests, ranging from core interests relating to risk perception, information technology careers, teaching IT e-business to more personal interests in literature, art history and film.

Michael Lane is a lecturer in the Division of Information Systems, Faculty of Business, University of Southern Queensland. He holds an Honours in Information Technology from the same university and recently completed a $\mathrm{PhD}$ with a focus in E-Commerce Development. He has published widely in Information Systems and Electronic Commerce and has varied interests in research and teaching. He has run a postgraduate course on E-Business Strategy at the Australian Graduate School of Business at USQ for the last four years. 